\title{
Analisis Implementasi Pembelajaran Daring Pada Masa New Normal (Studi Kasus di Program Studi S1 Pendidikan Ekonomi FKIP UKSW Salatiga)
}

\author{
Eka Yuliana Rahmawati*, Arief Sadjiarto, Tri Nugroho Budi Santoso \\ Program Studi Pendidikan Ekonomi, Fakultas Keguruan dan Ilmu Pendidikan, \\ Universitas Kristen Satya Wacana \\ *Corresponding Author. Email: ekayulianarahmawati@gmail.com
}

\begin{abstract}
This study aims to analyze the implementation of online learning during the New Normal at the SWCU Salatiga FKIP Economic Education Study Program. This research was a qualitative descriptive case study involving informants, namely the Head of Study Program, Lecturers, and Students. Data collection techniques are interviews, observation, and documentation. Meanwhile, the data analysis technique used was the Miles and Huberman Interactive model, namely the stages of data collection, data reduction, data presentation, and concluding/verification. The results showed that the implementation of online learning in the SWCU Salatiga FKIP Economic Education Undergraduate Study Program had been running well and effective. The ability of lecturers in managing the online learning was good, student responses during the implementation of online learning were quite good, students and lecturers already had the facilities needed to support the implementation of the online learning. The implementation of online learning was felt to be more flexible, some students felt more active, and could hone their skills and improve the ability of students and lecturers to use and operate technology. Common obstacles were network constraints and some students found that material delivered online was sometimes difficult to understand.
\end{abstract}

Abstrak: Penelitian ini bertujuan untuk menganalisis implementasi pembelajaran daring pada masa new normal di Program Studi Pendidikan Ekonomi FKIP UKSW Salatiga. Penelitian ini merupakan penelitian studi kasus yang bersifat deskriptif kualitatif dengan melibatkan informan yaitu Kaprodi, Dosen, dan Mahasiswa. Teknik pengumpulan data yaitu dengan wawancara, observasi dan dokumentasi. Sedangkan, teknik analisis data yang digunakan adalah model Interaktif Miles dan Huberman yaitu dengan tahap-tahap pengumpulan data, reduksi data, penyajian data, dan penarikan kesimpulan/verifikasi. Hasil penelitian menunjukkan bahwa implementasi pembelajaran daring di Program Studi S1 Pendidikan Ekonomi FKIP UKSW Salatiga sudah terlaksana dengan baik dan cukup efektif. Kemampuan dosen dalam mengelola pembelajaran daring sudah baik, respon mahasiswa selama pelaksanaan pembelajaran daring cukup baik, mahasiswa maupun dosen telah memiliki fasilitas-fasilitas yang dibutuhkan untuk mendukung pelaksanaan pembelajaran daring. Pelaksanaan pembelajaran daring dirasa lebih fleksibel, beberapa mahasiswa merasa lebih aktif, serta dapat mengasah dan meningkatkan kemampuan mahasiswa maupun dosen dalam menggunakan dan mengoperasikan teknologi. Kendala yang sering dialami adalah kendala jaringan dan beberapa mahasiswa merasa jika materi yang disampaikan secara daring terkadang sulit untuk dipahami.

\section{Article History}

Received: 08-05-2021

Revised: 26-06-2021

Accepted: 31-07-2021

Published: 07-09-2021

Key Words:

Implementation, Online

Learning, New Normal.

\section{Sejarah Artikel}

Diterima: 08-05-2021

Direvisi: 26-06-2021

Disetujui: 31-07-2021

Diterbitkan: 07-09-2021

\section{Kata Kunci:}

Implementasi, Pembelajaran Daring, New Normal..

How to Cite: Rahmawati, E., Sadjiarto, A., \& Santoso, T. (2021). Analisis Implementasi Pembelajaran Daring Pada Masa New Normal (Studi Kasus di Program Studi S1 Pendidikan Ekonomi FKIP UKSW Salatiga). Jurnal Kependidikan: Jurnal Hasil Penelitian dan Kajian Kepustakaan di Bidang Pendidikan, Pengajaran dan Pembelajaran, 7(3), 619-630. doi:https://doi.org/10.33394/jk.v7i3.3839 


\section{Pendahuluan}

Dunia Pendidikan dari waktu ke waktu mengalami perkembangan. Salah satu perkembangan tersebut adalah adanya inovasi dalam menggunakan metode pembelajaran baik di jenjang Sekolah Dasar hingga Perguruan Tinggi. Pelaksanaan perkuliahan saat ini tidak hanya dilakukan dengan tatap muka secara langsung, akan tetapi sudah mulai menerapkan pembelajaran daring (dalam jaringan) atau dilakukan secara online. Sanjaya (2020) berpendapat bahwa Pembelajaran Daring adalah pembelajaran jarak jauh/distancing learning dimana pembelajaran tidak dilakukan secara langsung, tetapi tatap muka dan komunikasi dilakukan melalui video conference, materi dan tugas diunduh serta diunggah melalui internet. Sehingga, dapat dikatakan bahwa pembelajaran daring yaitu perkuliahan yang pembelajarannya dilakukan secara online dengan memanfaatkan teknologi dan internetmelalui aplikasi-aplikasi seperti Google Meet, Zoom, Edmodo dan aplikasi pembelajaran lain.Pembelajaran daring adalah suatu inovasi yang terjadi di bidang pendidikan dengan melibatkan teknologi informasi dalam proses pembelajaran (Fitriyani dkk, 2020). Pembelajaran daring atau terkenal dengan e-Learning akan berpengaruh terhadap transformasi dunia pendidikan dari tradisional (konvensional) yang lebih menggunakan metode ceramah dan tatap muka langsung menuju ke bentuk digital (Online) baik secara sistem maupun isi/konten (Mutia dan Leonard, 2013).

Pembelajaran daring yang dapat dilakukan melalui jarak jauh dirancang agar dapat mengatasi adanya keterbatasan baik waktu, tempat, dan jarak ketika melakukan proses pembelajaran (Abidin dkk, 2020). Melalui pembelajaran daring proses pembelajaran diharapkan dapat dilaksanakan lebih fleksibel karena mahasiswa dapat belajar kapan saja dan di mana saja asal koneksi internet memadai. Dikarenakan bersifat fleksibel membuat pembelajaran daringdapat menjadi salah satu pembelajaran yang diterapkan untuk hal yang mendesak, yang membuat pembelajaran tatap muka secara langsung tidak dapat dilakukan. Seperti keadaan saat ini yaitu adanya pandemi Covid-19 (Coronavirus Disease 2019) pada tahun 2020 yang merebak di berbagai belahan negara termasuk Indonesia. “... Virus corona merupakan keluarga besar dari virus yang menyebabkan penyakit ringan hingga berat, seperti pilek hingga penyakit serius seperti MERS dan SARS" (www.kemkes.go.id) dalam artikel "Tentang Novel Coronavirus (NCOV)". Pandemi Covid-19 berdampak pada berbagai bidang, selain pada bidang perekonomian juga mulai merambah ke bidang pendidikan.Penyebaran Covid-19 yang terus meningkat mendorong pemerintah pusat maupun daerah untuk mengeluarkan kebijakan meliburkan lembaga pendidikan. Libur disini dimaksudkan bahwa sementara kuliah atau pembelajaran secara langsung ditiadakan dan para mahasiswa belajar di rumah. Hal tersebut dilakukan untuk menerapkan kebijakan pemerintah yaitu Social Distancing (menjaga jarak atau pembatasan sosial) yang kemudian dirubah menjadi Physical Distancing (pembatasan jarak fisik) guna meminimalisir dan memutus rantai penyebaran virus tersebut.

Setelah adanya kebijakan physical distancing, masyarakat mulai memasuki tatanan hidup baru yang disebut sebagai "New Normal". Masa new normal merupakan sebuah perubahan gaya hidup atau perilaku untuk tetap melakukan aktivitas seperti biasa namun membiasakan budaya hidup bersih, sehat dan tetap mematuhi protokol kesehatan untuk mencegah penularan dan persebaran virus corona (Covid-19). New normal mulai diterapkan pada berbagai bidang kehidupan tanpa terkecuali pada bidang pendidikan (Utami dkk, 2021). Pada bidang pendidikan ditindaklanjuti melalui Kementrian Pendidikan dan Kebudayaan (Kemendikbud), salah satunya dengan cara mengeluarkan Surat Edaran Nomor 4 Tahun 2020 tentang Pelaksanaan Kebijakan Pendidikan dalam Masa Darurat Penyebaran Corona Virus Disease (Covid-19).Surat tersebut berisi himbauan agar kegiatan pembelajaran dilakukan 
melalui pembelajaran jarak jauh atau daring dari rumah yang dilaksanakan untuk memberikan pengalaman belajar yang bermakna bagi peserta didik, tanpa terbebani tuntutan menuntaskan seluruh capaian kurikulum untukkenaikan kelas maupun kelulusan.Himbauan tersebut telah mendapat tanggapan dari banyak Perguruan Tinggi. Telah banyak Perguruan Tinggi yang melaksanakan perkuliahan secara daring dari rumah. Kemendikbud menyatakan paling tidak sudah terdapat 65 Perguruan Tinggi yang pembelajarannya dilaksanakan dari rumah guna meminimalisir penyebaran Covid-19 (CNN Indonesia, 16 Maret 2020).

Salah satu perguruan tinggi yang melaksanakan kebijakan berdasarkan surat edaran tersebut adalah Universitas Kristen Satya Wacana (UKSW) yang terletak di Kota Salatiga Provinsi Jawa Tengah. Menanggapi kebijakan pemerintah mengenai pendidikan di masa pandemi, perguruan tinggi UKSW membuat kebijakan dengan mengeluarkan Surat Edaran Rektor No. 148/Rek./3/2020 tanggal 16 Maret 2020 Tentang Penyesuaian Pelaksanaan Kegiatan Perkuliahan dan Kemahasiswaan Berkaitan dengan Pandemi Covid 19 yang diantaranya berbunyi:

“... kegiatan belajar mengajar di UKSW tetap berjalan tetapi dilaksanakan secara online (daring) menggunakan aplikasi-aplikasi seperti F-learn, Zoom, Google Classroom, WA, Email dan platform lainnya untuk melaksanakan prinsip Social Distancing/Physical Distancing. Selain itu, Seminar Proposal, Tugas Akhir, Tes Akhir dan Evaluasi penugasan juga dilaksanakan secara online. Kebijakan akan disesuaikan dengan perkembangan situasi ...”.

Adanya surat edaran Rektor tersebut yang menghimbau agar pelaksanaan perkuliahan dilakukan secara daring, maka seluruh Fakultas dan Program Studi yang ada di UKSW melakukan pembelajaran dari rumah (daring). Pendidikan Ekonomi sebagai salah satu program studi yang ada di FKIP UKSW juga telah mematuhi peraturan dari kampus yaitu melaksanakan proses pembelajaran secara daring. Mahasiswa di Program Studi Pendidikan Ekonomi bersama dengan dosen melakukan pembelajaran melalui F-Learn, Zoom, Meet, WhatsApp Group dan aplikasi pendukung pembelajaran daring lainnya. Pembelajaran daring yang diterapkan pada perkuliahan, diharapkan dapat menjadi metode pembelajaran yang efektif.

Berdasarkan hasil observasi awal yang dilakukan pada sebagian mahasiswa dari beberapa program studi di lingkungan FKIP, diperoleh bahwa UKSW telah mulai menerapkan pembelajaran daring (online) dari sebelum adanya pandemi Covid-19, termasuk juga di Program Studi Pendidikan Ekonomi FKIP UKSW. Pelaksanaan kuliah daring tersebut dilakukan dengan Flearn (Flexible Learning), yang merupakan fasilitas penunjang untuk belajar secara daring yang dimiliki oleh Universias Kristen Satya Wacana (UKSW). Akan tetapi, penggunaan pembelajaran daring belum dilaksanakan dengan maksimal. Pelaksanaan pembelajaran daring lebih digiatkan lagi ketika terjadinya pandemiCovid-19 ini. Menurut beberapa mahasiswa, mereka mengungkapkan bahwa kuliah secara daring memiliki kendala jaringan internet yang terkadang kurang lancar, ketersediaan paket data/kuota apalagi jika kelas online menggunakan google meet dan Zoom atau aplikasi video Conference lainnya membutuhkan kuota yang lebih banyak daripada menggunakan forum diskusi chat. Penyampaian materi kuliah secara online juga terkendala pada pemahaman isi materi, mungkin sebagian mahasiswa dapat memahami materi yang disampaikan, namun terdapat juga mahasiswa yang kurang paham dengan materi yang disampaikan secara daring. Karena tingkat pemahaman setiap mahasiswa berbeda, ada yang paham hanya dengan membaca materi namun juga ada yang paham dengan cara dijelaskan secara langsung oleh dosen pengajar. Hal tersebut sesuai dengan hasil penelitian Hariyanti, dkk (2020) yang mengungkapkan bahwa kendala pembelajaran daring yang dihadapi mahasiswa antara 
lainadalah kuota internet (faktor eksternal) dan pemahaman mahasiswa terhadap materi (faktor internal).

Kendala-kendala yang terjadi dapat menjadi hambatan pelaksanaan pembelajaran daring yang menyebabkan pembelajaran daring tidak berjalan secara maksimal dan menjadi tidak efektif.Agar dapat mencapai konsep pembelajaran yang efektif dan efisien maka pendidik dan peserta didik perlu memiliki hubungan timbal balik untuk mencapai tujuanbersama, perlu menyesuaikan dengan media pembelajaran, kondisi lingkungan sekolah, sarana dan prasarana (Rohmawati, 2015). Adapun penelitian ini bertujuan untuk menganalisis implementasi pembelajaran daring pada masa new normal di Program Studi Pendidikan Ekonomi FKIP UKSW Salatiga. Penelitian ini perlu dilakukan karena hasil yang diperoleh dapat memberikan gambaran apakah pembelajaran daring pada Pendidikan Ekonomi dapat dilaksanakan secara baik dan efektif.

\section{Metode Penelitian}

Penelitian ini menggunakan pendekatan kualitatif dengan metode studi kasus yang bersifat deskriptif. Studi kasus merupakan eksplorasi dengan mengumpulkan informasi secara mendalam sehingga dapat mencapai pemahaman mendalam tentang suatu kasus (Fitrah dan Luthfiyah, 2017). Informan pada penelitian ini adalah Kaprodi, Dosen dan Mahasiswa pendidikan ekonomi di FKIP UKSW, dimana sampel diambil secara snowball. Pada penelitian ini menggunakan sumber data primer yang diperoleh langsung dari observasi dan wawancara serta sumber data sekunder yang diperoleh dari buku, jurnal, maupaun dokumen yang terkait. Teknik dalam memperoleh data dilakukan dengan observasi, wawancara, serta dokumentasi. Untuk analisis data pada penelitian ini menggunakan model Miles dan Huberman (Sugiyono, 2017) yaitu dengan tahap-tahap pengumpulan data, data reduksi, penyajian data, dan penarikan kesimpulan/verifikasi.

\section{Hasil Penelitian dan Pembahasan}

Berdasarkan penelitian yang dilakukan dan data yang telah diperoleh, maka akan disajikan hasil penelitian secara deskriptif. Penelitian ini memiliki tujuan untuk menganalisis implementasi pembelajaran daring pada masa new normal di Program Studi S1 Pendidikan Ekonomi FKIP UKSW Salatiga.

\section{Implementasi Pembelajaran Daring}

Semenjak adanya Covid-19 dan dikeluarkannya Surat Edaran dari pemerintah yang menganjurkan untuk melakukan kegiatan pembelajaran dari jarak jauh, menjadi salah satu acuan bagi Program Studi Pendidikan Ekonomi FKIP UKSW Salatiga untuk melaksanakan kegiatan pembelajaran secara daring. Implementasi pembelajaran daring di Pendidikan Ekonomi sudah terlaksana dengan baik dan cukup efektif. Hal tersebut dilihat dari: 1) Kemampuan dosen dalam mengelola pembelajaran, 2) Respon peserta didik terhadap pembelajaran daring, Ketersediaan sarana dan Prasarana (Fasilitas) berbasis digital, serta 4) Kelebihan dan Hambatan pembelajaran daring.

\section{a) Kemampuan Dosen dalam Mengelola Pembelajaran Daring}

Dalam pelaksanaan pembelajaran dibutuhkan peran penting dari pendidik (dosen) baik pada pembelajaran konvensional maupun daring. Kemampuan dosen untuk mengelola pembelajaran merupakan salah satu hal penting supaya proses pembelajaran dapat berlangsung dengan baik dan tujuan dari pembelajaran tersebutdapat dicapai. Kemampuan mengelola pembelajaran merupakan kemampuan daridosen sebagai pendidik dalam mengelola pembelajaran meliputi pemahaman terhadap peserta didik, perancangan dan pelaksanaan pembelajaran, evaluasi 
pembelajaran, serta pengembangan peserta didik agar dapat mengaktualisasikan potensi yang dimilikinya (Sutono, 2020).

Dalam pembelajaran daring dosen di Pendidikan Ekonomi UKSW sudah mengelola pembelajaran daring dengan cukup baik. Selama pembelajaran daring dosen menyiapkan perencanaan pembelajaran berupa RPS. Rencana Pembelajaran Semester (RPS) adalah rencana pembelajaran yang dibuat dan digunakan sebagai panduan dalammelaksanakan perkuliahan selama satu semester agar dapat mencapai capaian pembelajaran yang telah ditetapkan (Yanti dkk, 2019). Selain itu, setiap dosen juga selalu menyiapkan bahan ajar berupa materi yang akan disampaikan kepada mahasiswa.

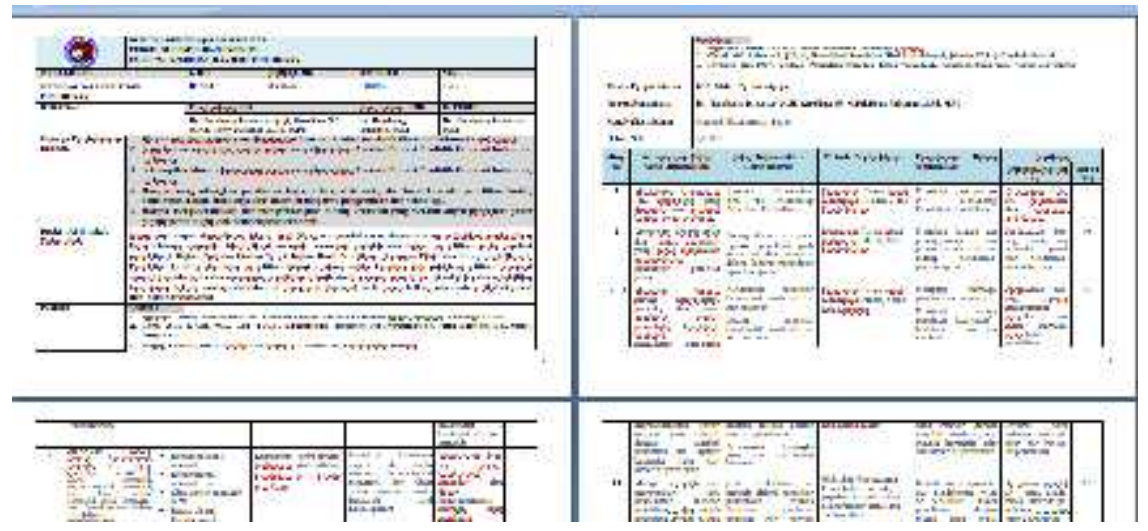

Gambar 1. RPS yang Disiapkan Dosen

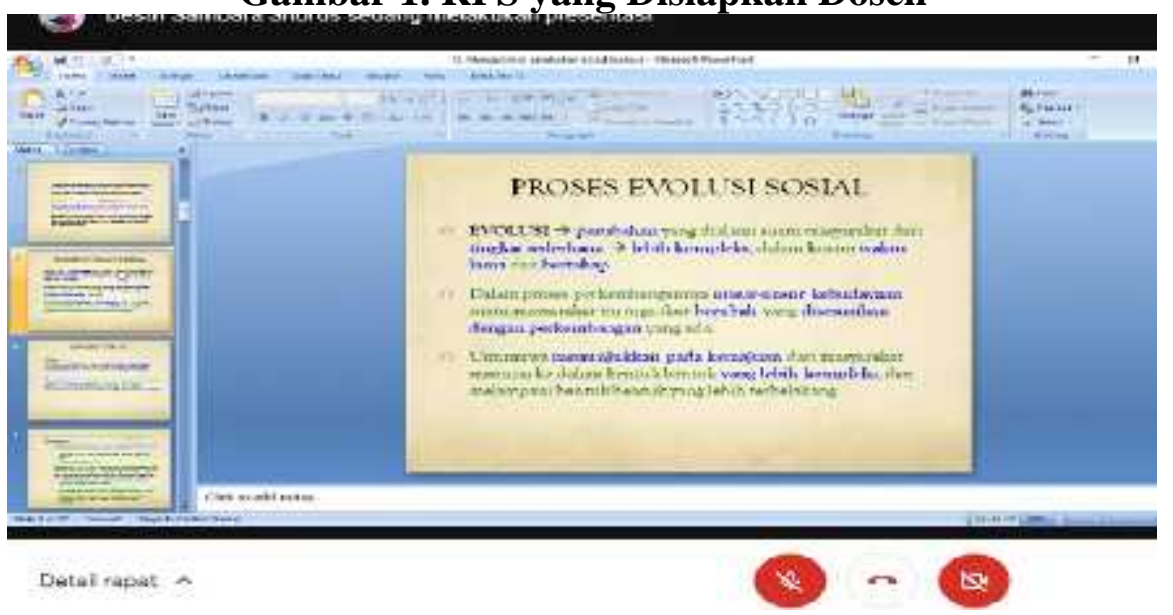

Gambar 2. Materi yang Disiapkan Dosen

Selain itu, dalam melaksanakan pembelajaran daring dosen sudah mampu menggunakan dan memanfaatkan teknologi dan internet. Dosen sudah bisa mengoperasikan HP dan laptop untuk menampilkan materi pembelajaran. Dosen tidak terlalu gagap terhadap teknologi karena sudah biasa mengajar secara daring melalui aplikasi pembelajaran online dan dapat memberikan materi, seperti menampilkan materi PPT melalui zoom/meet, dan membagikan melalui flearn. Dosen juga dapat menghubungkan perangkat pembelajarannyake jaringan internet. Kemampuan dosen dalam menggunakan teknologi juga diperlukan supaya kegiatan pembelajaran dapat berjalan dengan baik, apalagi dalam pembelajaran daring dimana pembelajarannya dilakukan secara online dan pastinya membutuhkan peran teknologi dan internet.

Penyajian materi pembelajaran dosen sudah cukup kreatif, karena dosen menyajikan materi tidak hanya dalam bentuk PPT, akan tetapi juga dengan video. Selain itu, mereka juga memberikan kesempatan kepada mahasiswa untuk presentasi 
dan berdiskusi sehingga tidak hanya dosen saja yang menyampaikan materi. Tetapi juga mahasiswa memiliki kesempatan untuk menyatakan ide atau gagasan mereka. Kreativitas dosen dalam menyampaikan dan menyajikan materi sangatlah diperlukan. Hal tersebut dikarenakan agar materi yang diberikan dapat menarik mahasiswa untuk belajar, mudah dimengerti serta materi tersebut menjadi bermakna (Hardianto, 2012).

Ketika akan melaksanakan pembelajaran dosen akan memikirkan serta mempersiapkan media yang akan digunakan. Pada pembelajaran daring tentunya menggunakan media yang memanfaatkan tekonologi internet. Media pembelajaran berbasis internet menjadi salah satu layanan yang banyak dimanfaatkan pendidik untuk melaksanakan pembelajaran maupun memberi penugasan kepada peserta didik untuk mencari informasi (Budiyono, 2020). Pelaksanaan pembelajaran daring di Program Studi Pendidikan Ekonomi dilakukan melalui berbagai media seperti melalui aplikasi zoom atau google meet sebagai virtual meetingnya. Selain itu, juga menggunakan WhatsApp yang digunakan untuk komunikasi antara dosen dan mahasiswa, seperti membagikan link pertemuan, memberikan referensi jurnal, atau bertukar informasi yang lainnya. Flearn (flexible learning) juga digunakan sebagai media pembelajaran karena pada platform ini juga dapat dimanfaatkan untuk membagikan materi, absensi, diskusi, tes maupun penugasan. Terkadang juga terdapat mata kuliah yang melaksanakan pembelajaran melalui google meet juga dilanjutkan dengan flearn. Media pembelajaran merupakan hal penting yang perlu disiapkan ketika akan melakukan pembelajaran karena dapat membantu agar proses pembelajaran berjalan dengan baik. Pembelajaran yang tidak disertai dukungan media pembelajaran yang baik akan menyulitkan dosen dalam mengajar atau menyampaikan materi dan juga menyulitkan mahasiswa dalam menyerap materi (Purba dkk, 2020).

Selama pelaksanaan pembelajaran daring, kondisi atau suasana kelas sudah cukup kondusif. Hal tersebut dikarenakan ketika dosen menjelaskan maka mikrofon mahasiswa dimatikan dan akan dinyalakan ketika memberikan pendapat atau bertanya. Selain itu, agar terjadi suasana kelas yang menarik dan terjadi diskusi maka dosen memancing mahasiswa dengan pertanyaan atau meminta mahasiswa untuk sharing. Menurut Munawaroh (2012) dosen memiliki tugas untuk menciptakan, memperbaiki, dan memelihara suasana kelas agar menjadi kelas yang kondusif.Suasana kelas ketika pelaksanaan pembelajaran daring tergantung dengan bagaimana cara dosen mengelola kelas tersebut agar kondusif, lebih hidup dan mengasyikkan. Pembelajaran daring yang dilaksanakan tidak secara tatap muka secara langsung atau dilakukan online membuat dosen sulit mengontrol mahasiswa secara langsung, namun dosen tetap mengupayakan untuk mengontrol jalannya pembelajaran dengan melalui absensi serta terkadang juga meminta mahasiswa untuk membuka kamera, dan juga mencatat daftar partisipan yang ada pada zoom/meet mahasiswa yang hadir selama virtual meeting. Karena pembelajaran daring dilakukan tanpa tatap muka langsung maka diperlukan adaya upaya dosen untuk tetapdapat mengawasi pembelajaran agar tetap berjalan dengan baik (Hardianto, 2012). Oleh karena itu, paling tidak dosen melakukan control kehadiran dengan absensi melalui flearn maupun siasat. 


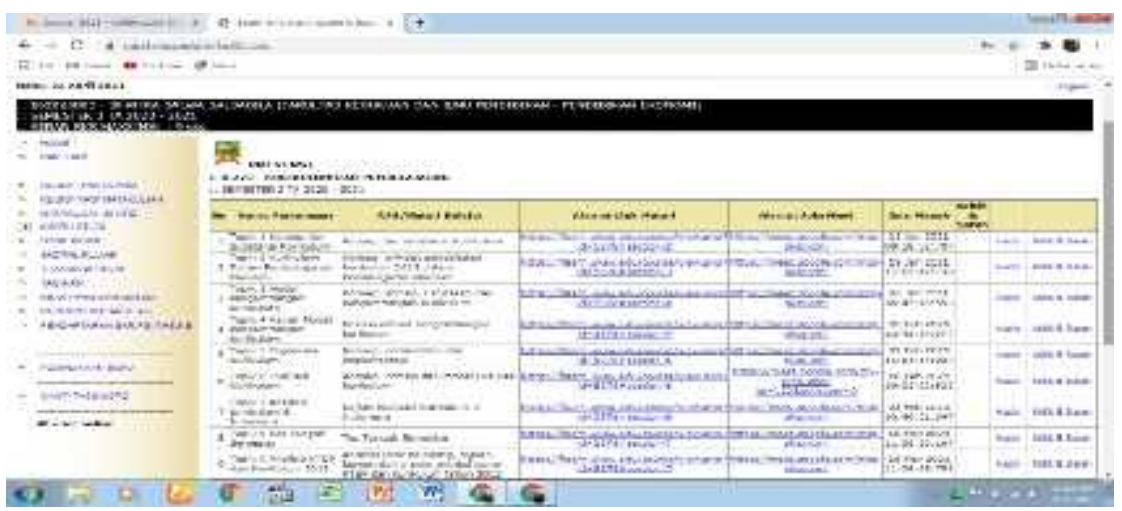

Gambar 3. Presensi Mahasiswa pada Siasat

Selanjutnya, untuk bentuk evaluasi atau penilaian yang dilakukan dosen terhadap mahasiswa yaitu dengan memberikan tugas yang biasanya dikirimkan melalui flearn. Selain itu, juga tes, presentasi serta membuat artikel atau makalah. Penilaian adalah salah satu hal penting dalam pembelajaran untuk mengetahui capaian kemampuan yang telah dikuasai oleh mahasiswa. Evaluasi dalam pembelajaran merupakan tahap untuk mengetahui keberhasilan pembelajaran yang hasilnya akan dijadikan sebagai feedback dalam memperbaiki kegiatan pembelajaran yang selanjutnya (Ismail, 2020).

\section{b) Respon Mahasiswa terhadap Pembelajaran Daring}

Dalamproses pembelajaran, selain diperlukan peran dari pendidik atau dosen juga diperlukan adanya respon dari mahasiswa. Diantara beberapa indikator pembelajaran yang efektif yang dikemukakan oleh Muis (2020) salah satunya adalah adanya respon positif dari peserta didik terhadap pembelajaran tersebut. Respon mahasiswa Program Studi Pendidikan Ekonomi sudah cukup baik.Dilihat dari kesiapan mahasiswa dalam melaksanakan pembelajaran daring persiapan yang mereka lakukan sudah cukup baik. Mahasiswa sudah mempersipakan segala sesuatu yang diperlukan selama pembelajaran daring seperti HP, Laptop, alat tulis dan jaringan internet (kuota atau Wifi). Selain itu, beberapa mahasiswa juga mendownload materi yang dibagikan oleh dosen untuk dibaca. Sehingga mereka sudah cukup siap untuk melakukan pembelajaran daring karena mereka sudah melakukan persiapanpersiapan tersebut. Menurut Slameto (Priyono dkk, 2021) Kesiapan merupakan seluruhan kondisi individu yang membuat mereka siap memberikan tanggapan atau respon dengan cara tertentu terhadap suatu kondisi atau situasi yang dihadapi. Kesiapan mahasiswa dalam proses pembelajaran perlu diperhatikan karena hasil belajarnya akan lebih baik jika sudah ada kesiapan pada diri mereka. Tanpa kesiapan dari mahasiswa maka pembelajaran yang dilaksanakan dapat memiliki pengaruh yang buruk terhadap proses pembelajaran (Priyono dkk, 2021).

Selanjutnya dari segi keaktifan mahasiswa selama pelaksanaan pembelajaran daring setiap mahasiswa memiliki tingkat keaktifan yang berbeda-beda. Terdapat mahasiswa yang aktif seperti memberikan tanggapan, sharing, atau bertanya kepada dosen. Namun selain itu juga masih terdapat mahasiswa yang kurang aktif, diam saja ketika kelas. Terkadang keaktifan mereka juga tergantung pada pemahaman mereka terhadap materi atau berdasarkan pada stimulus yang diberikan oleh dosen. Agar mahasiswa aktif ketika pembelajaran biasanya dosen memberikan stimulus seperti memberikan pertanyaan yang menuju kearah diskusi agar mahasiswa dapat mengemukakan ide gagasan atau argumentasinya. Menurut Fahrudin dan Fauziah 
(2020) keaktifan mahasiswa dapat terlihat dari pengajuan pertanyaan maupun dengan menyampaikan argumen mereka tentang materi yang dipahami.

Jika dilihat dari kedisiplinan mahasiswa yaitu dari kedisiplinan ketika masuk kelas dan pengumpulan tugas maka mahasiswa sudah cukup disiplin. Sebelum pelajaran dimulai mahasiswa sudah masuk kelas (zoom atau meet) meskipun terkadang masih ada beberapa mahasiswa yang terlambat. Beberapa dari mereka mengatakan jika keterlambatan mereka terkadang dipengaruhi oleh kendala sinyal dan ada kegiatan lain. Namun, untuk masuk kelas biasanya dosen memberikan kelonggaran waktu sekitar 10-15 menit, jika sudah melebihi waktu tersebut maka pelajaran akan dimulai. Sedaangkan dalam pengumpulan tugas mahasiswa sudah banyak yang tepat waktu, meskipun terkadang mereka mengumpulkannya mepet dengan batas waktu yang diberikan tetapi tidak sampai terlambat. Hanya beberapa mahasiswa saja yang sesekali kumpul terlambat. Hal tersebut dapat dilihat dari gambar di bawah ini yang menunjukkan keterangan mahasiswa dalam mengumpulkan tugas dif learn dan terdapat keterangan waktu sehinggan dapat diketahui mahasiswa yang mengumpulkan tepat waktu atau yang terlambat mengumpulkannya.

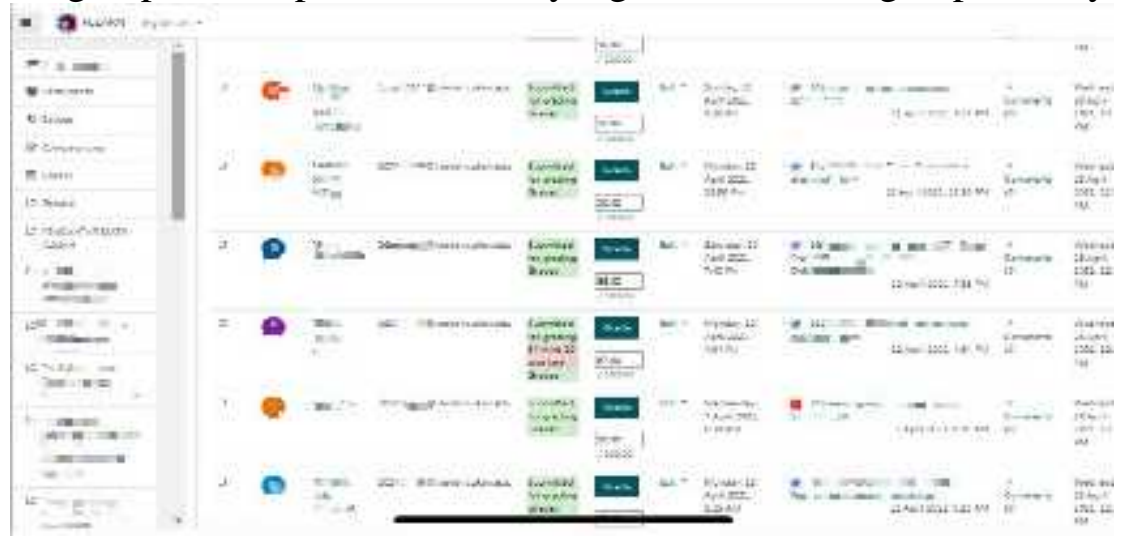

Gambar 4.Dokumentasi Pengumpulan Tugas Mahasiswa

Padapelaksanaan pembelajaran daring, mahasiswa sudah mulai menyesuaikan diri dengan media-media yang digunakan untuk pembelajaran daring. Mahasiswa sudah memilikikemampuan dalam menggunakan media pembelajaran daring karena sudah terbiasa mengoperasikan HP dan laptop. Mahasiswajuga sudah beradaptasi dan menyesuaikan dengan media yang digunakan oleh dosen serta memanfaatkan fiturfitur yang ada di google meet, zoom dan flearn. Selain itu, mereka juga bisa membuat video dan powerpoint (PPT) dengan memanfaatkan aplikasi seperti Powtoon.

\section{c) Ketersediaan Sarana atau Prasarana (Fasilitas) berbasis Digital}

Berdasarkanhasil penelitian yang dilakuakan pada mahasiswa maupun dosen Program Studi Pendidikan Ekonomi ditemukan bahwa sebagian besar sudah memiliki fasilitas Handphone, laptop, dan juga mereka juga memiliki kuota dan sebagian sudah memakai wifi di rumah. Sarana dan prasarana pembelajaran merupakan semua peralatan yang diperlukan untuk menukung kegiatan pembelajaran baik langsung maupun tidak langsung (Purba dkk, 2021). Sarana dan prasarana atau fasilitas menjadi salah satu hal penting yang dapat menunjang kegiatan pembelajaran, termasuk dalam pelaksanaan pembelajaran daring. Hal tersebut didukung dengan yang diungkapkan oleh Dalyono (Purba dkk, 2021) bahwa sarana dan prasarana pembelajaran yang lengkap akan membantu belajar peserta didik, sedangkan sarana dan prasarana belajar yang kurang lengkap akan menghambat kegiatan belajar peserta didik. Jika sarana dan prasarana fasilitas pendidikan dapat terpenuhi maka pembelajaran daring dapat 
menjadi inovasi pendidikan dalam mecinciptakan proses pembelajaran yang bersifat fleksibel karena dapat dilakukan dimanapun dan kapanpun, dapat memudahkan interaksi antara pendidik dan peserta didik dalam berbagi informasi mengenai pengetahuan dengan bantuan internet, pengetahuan dan wawasan pendidik serta peserta didik akan lebih luas karena cakupan informasi yang diperoleh melalui internet sangat luas (Wulandari dkk, 2020).

\section{d) Kelebihan dan Hambatan Pembelajaran Daring}

Darihasil penelitian terhadap pelaksanaan pembelajaran daring di Program Studi Pendidikan Ekonomi UKSW Salatiga, ditemukan beberapa kelebihan yang dirasakan baik dosen maupun mahasiswa. Pelaksanaan pembelajaran daring bersifat lebih fleksibel karena dapat dilakukan kapanpun dan dimanapun. Sehingga dosen dan mahasiswa tidak perlu bertemu tatap muka secara langsung di kampus tetapi bisa dilakukan dari tempat masing-masing dan tugas juga dapat dikumpulkan secara online. Menurut (Yuliani dkk, 2020) secara umum kelebihan dari pembelajaran daring adalah tidak terikat oleh waktu dan tempat sertawaktu yang digunakan juga lebih leluasa.Selain itu, baik mahasiswa maupun dosen menjadi lebih terbiasa dalam menggunakan teknologi serta memanfaatkan aplikasi-aplikasi pembelajaran karena terjadi pengaplikasian teknologi secara langsung. Menurut Yuliani (2020) Pembelajaran daring dapat memenuhi tujuan dari pendidikan dalam pemanfaatan teknologi iformasi dengan menggunakan gadget atau laptop yang terhubung ke internet. Adanya perkembangan teknologi yang semakin pesat mempermudah dunia pendidikan dalam melangsungkan kegiatan pembelajaran.Beberapa mahasiswa juga merasakan jika pembelajaran daring membuat mereka menjadi lebih aktif daripada ketika pembelajaran tatap muka langsung. Hal tersebut dikarenakan ketika pembelajaran daring mereka menjadi lebih percaya diri untuk berbicara. Hal tersebut juga sesuai dengan pernyataan Astuti dan Febrian (2019) bahwa mahasiswa menyatakan jika mereka lebih percaya diri untuk terlibat secara aktif dalam pembelajaran daring daripada tatap muka langsung.

Selain itu, selama pelaksanaan pembelajaran daring masih ditemuihambatanhambatan.Berdasarkan dari hasil penelitian hambatan yang ditemukan selama pembelajaran daring yang dialami dosen dan mahasiswa di Pendidikan Ekonomi antara lain adalah kendala teknis dan juga terdapat mahasiswa yang kurang paham terhadap materi. Kendala teknis yang sering dihadapi dosen dan mahasiswa adalah kendala jaringan, yang dapat disebabkan oleh mati lampu atau hujan. Hal tersebut yang membuat suara terkadang putus-putus dan juga akun zoom atau meet keluarmasuk sendiri (error) sehingga mengganggu pembelajaran daring. Hal tersebut sesuai dengan pendapat dari Dewi (2020) bahwa jaringan yang terganggu atau hilang secara tiba-tiba membuat mahasiswa terganggu dalam menerima materi yang diberikan dosen.Selain itu, beberapa mahasiswa merasa kurang paham terhadap materi yang disampaikan dosen. Hal tersebut dapat dikarenakan setiap mahasiswa memiliki kemampuan masing-masing dalam menerima materi. Meskipun secara daring dosen sudah menjelaskan materi namun terdapat mahasiswa yang bisa paham dengan materi yang disampaikan secara daring, dan ada mahasiswa yang paham materi jika dijelaskan secara langsung. Hal tersebut sesuai yang diungkapkan oleh Fahrudin dan Fauziah (2020) bahwa meskipun powerpoint atau materi yang dipaparkan melalui media sosial sudah disertai penjelasan baik tulisan maupun audio, namun belum tentu dapat memberikan pemahaman maksimal kepada masing-masing mahasiswa karena 
setiap mahasiswa mempunyai kemampuan yang berbeda dalam memahami materi yang disampaikan oleh dosen.

\section{Kesimpulan}

Kesimpulan yang diperoleh dari hasil penelitian ini antara lain adalah: (1) Implementasi pembelajaran daring di Program Studi S1 Pendidikan Ekonomi FKIP UKSW Salatiga sudah terlaksana dengan baik dan cukup efektif. (2) Kemampuan dosen dalam mengelola pembelajaran daring sudah baik karena dosen sudah mempersiapkan bahan ajar sesuai dengan RPS, kreatif dalam menyampaikan materi dengan memanfaatkan teknologi dan internet, menggunakan media pembelajaran yang beragam serta berupaya untuk menghidupkan suasana kelas agar kondusif dan menarik. (3) Respon yang diberikan mahasiswa selama pelaksanaan pembelajaran daring cukup baik. (4) Mahasiswa maupun dosen telah memiliki fasilitas-fasilitas yang dibutuhkan untuk mendukung pelaksanaan pembelajaran daring. (5) Pelaksanaan pembelajaran daring lebih fleksibel karena dapat dilakukan dimana pun dan kapan pun tanpa harus bertemu langsung di kampus atau kelas. Selain itu, beberapa mahasiswa merasa lebih aktif selama pembelajaran daring, serta dapat mengasah dan meningkatkan kemampuan mahasiswa maupun dosen dalam menggunakan dan mengoperasikan teknologi. (6) Kendala yang sering dialami adalah kendala jaringan, dan beberapa mahasiswa ada yang merasa jika materi yang disampaikan secara daring terkadang sulit untuk dipahami.

\section{Saran}

Saran yang dapat disampaikan berdasarkan hasil penelitian ini antara lain adalah: (1) Bagi Universitas, Fakultas, maupun Program Studi hendaknya mengecek pendataan nomor dosen dan mahasiswa agar sinkron dengan data yang didaftarkan untuk subsidi kuota dari pemerintah terutama untuk dosen dan mahasiswa baru. (2) Baik dosen maupun mahasiswa sebaiknya memanfaatkan fasilitas dengan maksimal, khususnya dalam pelaksanaan pembelajaran daring baik di rumah/ di luar rumah maupun kampus agar proses pembelajaran juga dapat berjalan dengan baik. (3) Bagi dosen sebaiknya lebih rutin untuk membuat video pembelajaran atau merekam proses pembelajaran terutama ketika menjelaskan materi, dan kemudian dapat dibagikan kepada mahasiswa agar mahasiswa dapat mengulang kembali materi yang kurang dipahami. (4) Bagi mahasiswa hendaknya dapat memanfaatkan pembelajaran daring ini sebagai langkah untuk menguatkan kemandirian dan belajar kedisiplinan dalam setiap mata kuliah yang diikuti. (5) Bagi peneliti selanjutnya diharapkan penelitian dengan tema serupa dapat mengkaji lebih dalam lagi mengenai pelaksanaan pembelajaran daring, misalnya lebih memfokuskan untuk mengkaji kurikulum atau RPS yang dibuat oleh Program Studi dan evaluasi pembelajaran yang berkaitan dengan penjaminan mutu program studi.

\section{Daftar Pustaka}

Abidin, Z., Hudaya, A., \& Anjani, D. (2020). Efektivitas Pembelajaran Jarak Jauh Pada Masa Pandemi Covid-19. Research and Development Journal of Education, 1(1), 131-146.

Astuti, P.,\& Febrian, F.(2019). Blended Learning Syarah: Bagaimana Penerapan dan Persepsi Mahasiswa. Jurnal Gantang, 4(2), 111-119.

Budiyono, B. (2020). Inovasi Pemanfaatan Teknologi Sebagai Media Pembelajaran di Era Revolusi 4.0. Jurnal Kependidikan: Jurnal Hasil Penelitian dan Kajian Kepustakaan di Bidang Pendidikan, Pengajaran dan Pembelajaran, 6(2), 300309.doi:https://doi.org/10.33394/jk.v6i2.2475 
CNN Indonesia. 2020. 65 Kampus Kuliah dari Rumah, Sultan Yogyakarta Ragukan $\begin{array}{lllll}\text { Efektivitas. } & \text { Diunggah } & \text { pada } & 16 & \text { Maret }\end{array}$ https://www.cnnindonesia.com/nasional/20200316110707-20-483756/65-kampuskuliah-dari-rumah-sultan-yogya-ragukan-efektivitas (Di akses pada 4 Juni 2020 pukul 00.54).

Dewi, S. N. (2020). Dampak Covid19 Terhadap Pembelajaran Daring di Perguruan Tinggi. Jurnal Pendidikan Ilmu Pengetahuan Sosial (JPIPS), 12(2), 87-93.

Fahrudin, A., \& Fauziah, A. (2020). Pengaruh Pembelajaran Online terhadap Kemampuan Literasi, Keaktifan, dan Tingkat Pemahaman Mahasiswa pada Mata Kuliah Sains dalam Al-Qur'an di IAIN Tulungagung. EDUDEENA: Journal of Islamic Religious Education, 4(2), 95-105.

Fitrah, Muh., \& Luthfiyah. (2017). Metodologi Penelitian; Penelitian Kualitatif, Tindakan Kelas \& Studi Kasus. Sukabumi: CV Jejak.

Fitriyani, Y., Fauzi, I., \& Sari, M. (2020). Motivasi Belajar Mahasiswa Pada Pembelajaran Daring Selama Pandemik Covid-19. Jurnal Kependidikan: Jurnal Hasil Penelitian dan Kajian Kepustakaan di Bidang Pendidikan, Pengajaran dan Pembelajaran, 6(2), 165-175. doi:https://doi.org/10.33394/jk.v6i2.2654

Hardianto, D. (2012). Karakteristik Pendidik dan Peserta Didik dalam Pembelajaran Online. Jurnal Majalah Ilmiah Pembelajaran, 8(2), 1-10.

Hariyanti, D., Mun'im, A. H., \& Hidayat, N. (2020). Identifikasi hambatan mahasiswa dalam pelaksanaan pembelajaran biologi secara daring selama pandemi covid-19 di kabupaten jember. ALVEOLI: Jurnal Pendidikan Biologi, 1(1), 11-21.

Ismail, Muhammad. I.(2020). Evaluasi Pembelajaran: Konsep dasar, Prinsip, Teknik, dan Prosedur. Depok: Rajawali Pers.

Kemdikbud. 2020. SE Mendikbud: Pelaksanaan Kebijakan Pendidikan dalam Masa Darurat Penyebaran Covid-19.https://www.kemdikbud.go.id/main/blog/2020/03/semendikbud-pelaksanaan-kebijakan-pendidikan-dalam-masa-darurat-penyebarancovid19 (Diakses: 20 Februari 2021, pukul: 15.44 WIB).

Kemkes."Tentang Novel Coronavirus https://www.kemkes.go.id/download.php?file=download/info-terkini/COVID19/TENTANG\%20NOVEL\%20CORONAVIRUS.pdf. (Diakses pada 03 Juni 2020 pukul 21.37).

Muis, M. (2020). Model Pembelajaran Berbasis Masalah: Teori dan Penerapannya. Gresik: Caremedia Communication.

Munawaroh, Isniatun.(2012). Esensi "Menghidupkan" Ruang Kelas BagipenyelenggaraanPembelajaran Efektif. Jurnal Majalah Ilmiah Pembelajaran.

Mutia, I.,\& Leonard, L.(2013). Kajian penerapan e-learning dalam proses pembelajaran di perguruan tinggi. Faktor Exacta 6(4), 278-289.

Priyono, P. K.,Rusyani, Y., \& Hartono, B. (2021). Jurnal Kesiapan Mahasiswa pada Pembelajaran Dalam Jaringan (Daring) Saat Pandemi Covid-19 di STIKES Duta Gama Klaten. Jurnal Ilmu Kesehatan STIKES DUTA GAMA KLATEN,13(1),1-6.

Purba, R. A, dkk.(2020). Pengantar Media Pembelajaran. Penerbit: Yayasan Kita Menulis.

Purba, S., dkk. (2021). Analisis Kebijakan Pendidikan. Penerbit: Yayasan Kita Menulis.

Rektor UKSW. (2020). Surat Edaran RektorNo. 148/Rek./3/2020 Tanggal 16 Maret 2020 Tentang Penyesuaian Pelaksanaan Kegiatan Perkuliahan dan Kemahasiswaan Berkaitan dengan Pandemi Covid 19.

Rohmawati, Afifatu. (2015). Efektivitas Pembelajaran. Jurnal Pendidikan Usia Dini, 9(1), 15-32. 
Sanjaya, Ridwan. (2020). 21 Refleksi Pembelajaran Daring di Masa Darurat. Semarang: SCU Knowledge Media.

Sugiyono. (2012). Metode Penelitian Kuantitatif, Kualitatif dan R\&D. Bandung: ALFABETA,cv.

Sutono, A. (2020). Pariwisata dan Ketahanan Nasional. Bandung: UPI Press.

Utami, Rosanita T., dkk. 2021. New NormalEra dalam Berbagai Aspek Kehidupan. Yogyakarta: Zahir Publishing.

Wulandari, M. A., Arga, H. S.P., Kelana, J. B., Altaftazani, D. H., Ruqoyyah, S. (2020). Analisis pembelajaran "daring" pada guru sekolah dasar di era covid-19. Jurnal Ilmiah P2M STKIP Siliwangi, 7(2), 164-168.

Yanti, F. A., Mundlilarto, dan Heru. K. (2019). Teori dan aplikasi model cooperative research project based learning di perguruan tinggi. Yogyakarta: CV. Gre Publishing.

Yuliani, Meda., dkk. (2020). Pembelajaran Daring untuk Pendidikan: Teori dan Penerapan. Penerbit: Yayasan Kita Menulis. 